\title{
Vaginal Cancer Pathologic Primary Tumor TNM Finding v8
}

National Cancer Institute

\section{Source}

National Cancer Institute. Vaginal Cancer Pathologic Primary Tumor TNM Finding v8. NCI Thesaurus. Code C139640.

A pathologic finding about one or more characteristics of vaginal cancer, following the rules of the TNM AJCC V8 classification system as they pertain to staging of the primary tumor. The definitions of the T categories correspond to the stages accepted by FIGO. (from AJCC 8th Ed.) 